\title{
Analisa Kekuatan Spiral Bevel gear dengan Variasi Sudut Spiral Menggunakan Metode Elemen Hingga
}

\author{
Deta Rachmat Andika dan Agus Sigit Pramono \\ Jurusan Teknik Mesin, Fakultas T, Institut Teknologi Sepuluh Nopember (ITS) \\ Jl. Arief Rahman Hakim, Surabaya 60111 Indonesia \\ e-mail:pramono@me.its.ac.id
}

\begin{abstract}
Abstrak - Seiring perkembangan zaman, teknologi roda gigi dituntut untuk mampu mentransmisikan daya yang besar dengan efisiensi yang besar pula. Pada jenis intersecting shaft gear, tipe roda gigi payung spiral (spiral bevel gear) merupakan perkembangan dari roda gigi payung bergigi lurus (straight bevel gear ). Kelebihan dari spiral bevel gear antara lain adalah kemampuan transmisi daya dan efisiensi yang lebih besar pada geometri yang sama serta tidak terlalu berisik. Akan tetapi spiral bevel gear juga mempunyai kelemahan jika dibandingkan dengan straight bevel gear. Selain proses manufaktur yang lebih rumit, profil lengkung gigi spiral ini membuat distribusi tegangan yang terjadi menjadi lebih rumit untuk dimodelkan dengan persamaan matematika. Salah satu pendekatan yang dapat dilakukan adalah dengan menggunakan metode elemen hingga.

Penelitian diawali dengan membuat model dari straight bevel gear dan juga spiral bevel gear yang sudut spiralnya divariasikan 20, 35, dan 45 derajat. Model dibuat dengan dimensi yang sama baik diameter maupun jumlah gigi gear. Langkah selanjutnya yaitu perhitungan analitis pada straight bevel gear dimana hasilnya akan dibandingkan dengan hasil simulasi statis. Setelah eror yang terjadi dibawah $15 \%$ maka dilakukan simulasi dinamis pada semua model yang telah dibuat yaitu straight bevel dan juga spira bevel gear .

Hasil yang didapatkan dari penelitian ini adalah secara keseluruhan spiral bevel gear lebih kuat daripada straight bevel gear pada dimensi dan beban yang sama jika dilihat dari lebih kecilnya tegangan bending dan tegangan kontak maksimum yang terjadi. Tegangan terbesar terjadi pada jenis straight bevel gear baik pada tegangan bending maupun tegangan kontak sedangkan spiral bevel gear dengan variasi sudut spiral 35 mempunyai nilai tegangan terkecil. Prosntase selisih tegangan bending maksimum yang terjadi antara straight bevel gear dan spiral bevel gear dengan variasi sudut spiral 35 derajat sebesar 44,3\%. Sedangkan selisih tegangan kontak maksimumnya sebesar $20,5 \%$. Sehingga secara keseluruhan spiral bevel gear lebih baik daripada straight bevel gear.
\end{abstract}

Kata Kunci-- spiral bevel gear, tegangan bending , tegangan kontak, FEM.

\section{PENDAHULUAN}

$\mathrm{R}$ oda gigi (gear) merupakan salah satu elemen mesin yang berfungsi untuk mentransmisikan daya dari suatu poros ke poros lainnya. Perkembangan roda gigi dimulai pada tahun 330 SM oleh Aristoteles yang saat itu digunakan untuk menggerakan roda di mesin pengerek. Pada era moderen ini roda gigi sudah jauh berkembang baik dari sisi fungsi, bentuk profil, material, maupun proses manufakturnya. Berdasarkan aksisnya roda gigi dapat golongkan menjadi 3 jenis yaitu jenis roda gigi pararel (parallel shaft gear $s$ ), berpotongan (intersecting shaft gear s), dan bersilangan ( neither parallel nor intersecting shaft gear s).

Seiring perkembangan zaman, teknologi roda gigi dituntut untuk mampu mentransmisikan daya yang besar dengan efisiensi yang besar pula. Pada jenis intersecting shaftgear misalnya, tipe roda gigi payung spiral (spiral bevel gear) merupakan perkembangan dari roda gigi payung bergigi lurus ( bevel gear $)$. Kelebihan dari spiral bevel gear antara lain adalah kemampuan transmisi daya dan efisiensi yang lebih besar pada geometri yang sama serta tidak terlalu berisik. Akan tetapi spiral bevel gear juga mempunyai kelemahan jika dibandingkan dengan bevel gear. Selain proses manufaktur yang lebih rumit, perhitungan analitis tegangan bending pada spiral bevel gear juga belum banyak dibahas. Selama ini perhitungan analitis tegangan bending pada spiral bevel gear dapat diasumsikan sama dengan bevel gear yang sebenarnya mempunyai kekuatan lebih rendah daripada spiral bevel gear . Sehingga secara keseluruhan biaya manufaktur spiral bevel gear lebih mahal.

Perhitungan analitis tegangan bending pada spiral bevel gear lebih rumit karena bentuk profil giginya yang melengkung. Profil lengkung gigi spiral ini membuat distribusi tegangan yang terjadi menjadi lebih rumit untuk dimodelkan dengan persamaan matematika. Salah satu pendekatan yang dapat dilakukan adalah dengan menggunakan metode elemen hingga (finite element method). Inti dari FEM adalah membagi suatu benda yang akan dianalisa menjadi beberapa bagian dengan jumlah hingga (finite). Bagian-bagian ini disebut elemen yang tiap elemen satu dengan elemen lainnya dihubungkan dengan nodal (node). Kemudian dibangun persamaan matematika yang menjadi reprensentasi benda tersebut. Dengan demikian dapat diketahui berapa selisih kekuatan dari spiral bevel gear dan bevel gear sehingga biaya manufaktur spiral bevel gear dapat ditekan dengan cara menurunkan grade dari material yang digunakan.

Oleh karena itu perlu adanya suatu penelitian tentang analisa perbandingan tegangan bending yang terjadi pada bevel gear dan spiral bevel gear dengan menggunakan metode elemen hingga. Semakin besar selisih tegangan bending yang terjadi, semakin besar pula penurunan grade dari material yang digunakan. Variasi sudut spiral pada spiral bevel gear perlu dilakukan agar didapatkan hasil yang lebih maksimal. Sudut 
spiral yang umum digunakan pada spiral bevel gear adalah $20^{\circ}, 35^{\circ}$, dan $45^{\circ}[2]$.

\section{URAIAN PENELITIAN}

\section{A. Spiral Bevel gear}

Spiral bever gear mempunyai fungsi yang hampir sama dengan bevel gear. Perbedaan dari keduanya terletak pada bentuk profil giginya. Pada spiral bevel gear, profil gigi berbentuk lengkung seperti paying dengan jari-jari tertentu.

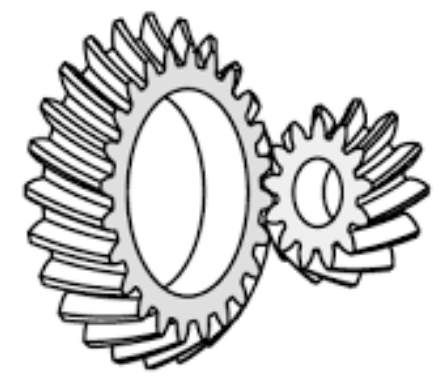

Gambar 1 Spiral bevel gear [1]

Dengan bentuk profil gigi ini, spiral bevel gear mempunyai banyak kelebihan jika dibandingkan dengan bevel gear antara lain :

- Pergerakan lebih halus sehingga noise lebih kecil

- Rasio reduksi kecepatan lebih besar

- Permukaan kontak lebih luas

- Gigi lebih kuat

- Kemampuan transmisi daya lebih besar dengan geometri yang sama

- Efisiensi lebih besar

Sudut spiral $\left(\beta_{m}\right)$ didefinisikan sebagai sudut yang dibentuk oleh sebuah garis yang menghubungkan titik pusat gear dan titik tengah dari lengkung spiral gigi dan sebuah garis lainnya yang menghubungkan pangkal gigi spiral dan titik tengah lengkung spiralnya. Sudut spiral dan parameter lainnya seperti face advance, lebar gigi, dan circular pitch ditunjukkan pada gambar 2.8. Untuk parameter lainnya seperti sudut poros dapat diasumsikan sama dengan bevel gear.

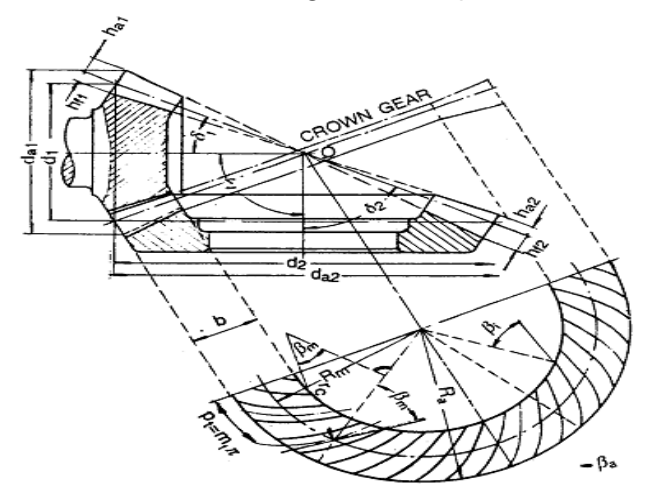

Gambar 3 Geometri spiral bevel gear [1]

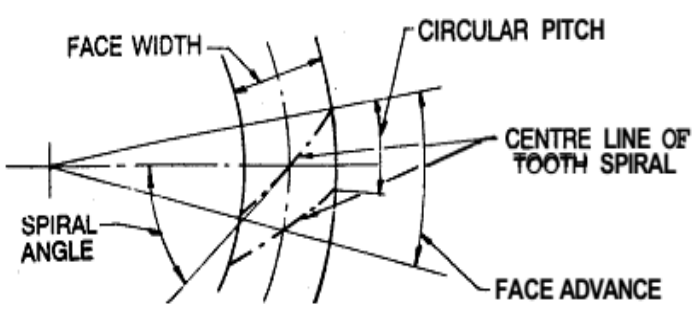

Gambar 2 Sudut spiral [1]

\section{B. Perhitungan Analitis Straight Bevel gear}

Perhitungan analitis pada bevel gear dilakukan untuk membandingkan dan menentukan apakah nilai tegangan hasil dari simulasi valid atau tidak. Dalam hal ini ditentukan apabila perbedaan antara hasil simulasi dan perhitungan analitis kurang dari $15 \%$ maka simulasi dapat dikatakan valid. Perhitungan analitis dilakukan dengan perumusan yang terdapat pada dasar teori berdasarkan persamaan Lewis sebagai berikut [2]:

$$
F_{b}=\frac{\sigma_{b} Y b}{P}\left(1-\frac{b}{L}\right)
$$

$\begin{array}{ll}\text { Dengan } & F_{b}=\frac{2 T_{1}}{d_{1}} \\ \text { Sehingga } & \sigma_{b}=\frac{2 T_{1} P}{Y\left(1-\frac{b}{L}\right) d_{1} b}\end{array}$

Dimana :

$F_{b}=$ Gaya bending

$\sigma_{b}=$ Tegangan bending

$P=$ Diameteral pitch

$\mathrm{b}=$ Face width

$\mathrm{L}=$ Jarak pitch menuju apex (cone distance)

$Y=$ Lewis factor

$\mathrm{T}=$ Tors

Untuk menghitung wear yang diijinkan digunakan persamaan Hertzian kontak stress sebagai berikut :

Dengan

$$
\sigma_{H}=\sqrt{\frac{2 \cdot T \cdot \cos y \cdot 1,4}{d p^{2} \cdot Q^{\prime} \cdot \sin \varnothing \cdot \cos \varnothing \cdot\left(\frac{1}{E 1}+\frac{1}{E 2}\right)}}
$$

Dimana :

$$
Q^{\prime}=\frac{2 N^{\prime}{ }^{\prime} t g}{N^{\prime}{ }_{t p}+N^{\prime} t g}
$$

$y=$ sudut pitch pinion

$\varnothing \quad=$ sudut tekan

$N^{\prime}{ }_{\mathrm{tg}}=$ formative number of pinion teeth

$N^{\prime}{ }^{\prime g}=$ formative number of gear teeth

$E \quad=$ modulus elastis

\section{Pemodelan}

Proses desain 3D dalam penelitian ini dilakukan dengan software solidworks. Tahapan-tahapan pada perencanaan desain terbagi menjadi 2 yaitu proses pembuatan part dan proses assembly. Sebelum dilakukan pemodelan, sebelumnya 
ditentukan dimensi dari gear yang akan dimodelkan. Data dari dimensi gear dapat dilihat pada tabel 1 berikut :

Tabel 1.

Dimensi Gear

\begin{tabular}{|c|c|c|c|c|c|c|c|c|c|}
\hline & \multicolumn{2}{|c|}{ Bevel gear } & \multicolumn{2}{|c|}{ spiral 20} & \multicolumn{2}{|c|}{ spiral35 } & \multicolumn{2}{|c|}{ spiral45 } & \multirow[b]{2}{*}{ Sat } \\
\hline & gr & Pn & gr & Pn & gr & Pn & gr & Pn & \\
\hline $\begin{array}{l}\text { Diame } \\
\text { tral } \\
\text { Pitch }\end{array}$ & 6 & 6 & 6 & 6 & 6 & 6 & 6 & 6 & \\
\hline $\begin{array}{l}\text { Modul } \\
\text { ar }\end{array}$ & 4.233 & 4.233 & 4.233 & 4.233 & 4.233 & 4.233 & 4.233 & 4.233 & \\
\hline $\begin{array}{c}\text { Pressu } \\
\text { re } \\
\text { Anole }\end{array}$ & 20 & 20 & 20 & 20 & 20 & 20 & 20 & 20 & deg \\
\hline $\begin{array}{l}\text { Angle } \\
\text { Spiral } \\
\text { Angle }\end{array}$ & 0 & 0 & 20 & 20 & 35 & 35 & 45 & 45 & deg \\
\hline $\begin{array}{c}\text { Ratio, } \\
1: x\end{array}$ & & & & & $1: 2$ & & & & \\
\hline $\begin{array}{l}\text { Numb } \\
\text { er of } \\
\text { Teeth }\end{array}$ & 36 & 18 & 36 & 18 & 36 & 18 & 36 & 18 & \\
\hline $\begin{array}{c}\text { Face } \\
\text { Width }\end{array}$ & 1 & 1 & 1 & 1 & 1 & 1 & 1 & 1 & in \\
\hline $\begin{array}{c}\text { Backla } \\
\text { sh }\end{array}$ & 0.005 & 0.005 & 0.005 & 0.005 & 0.005 & 0.005 & 0.005 & 0.005 & in \\
\hline Torque & & 2500 & & 2500 & & 2500 & & 2500 & $\begin{array}{l}\text { lbf/ } \\
\text { in }\end{array}$ \\
\hline $\begin{array}{c}\text { Rotati } \\
\text { onal } \\
\text { velocit } \\
y\end{array}$ & & 1000 & & 1000 & & 1000 & & 1000 & rpm \\
\hline
\end{tabular}

Proses pemodelan part dapat dibagi menjadi dua yaitu sket base dan sket gigi. Pada sket base dibuat sket dasar bevel gear pada sebuah bidang lalu digunakan fitur revolve base. Proses asembly merupakan penggabungan dari part pinion dan gear yang telah selesai dimodelkan.

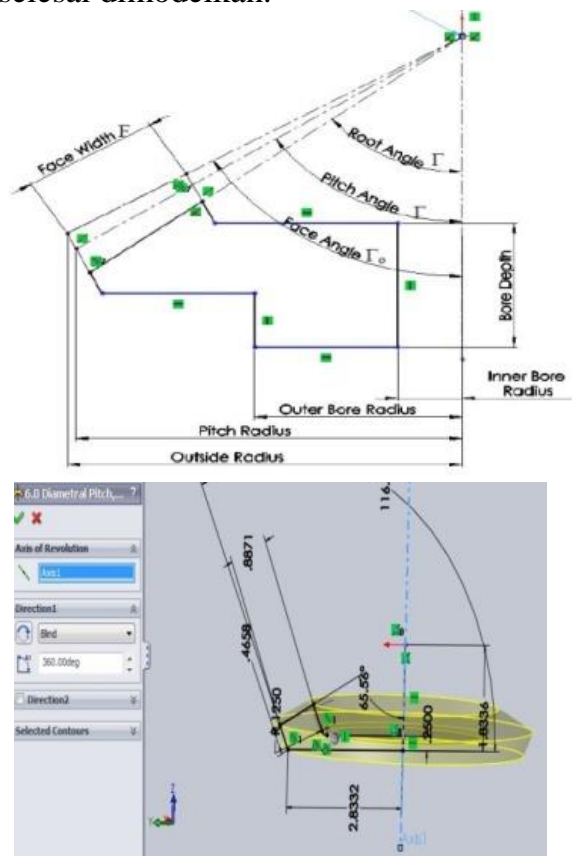

Gambar 4. Sket base bevel gear
Pada proses sket profil gigi involute dengan digunakan persamaan lengkung spiral berdasarkan persamaan parametrik sebagai berikut [3] :

$$
\begin{aligned}
& \mathrm{Db}=\mathrm{D} * \cos (\varnothing) \\
& \mathrm{x}(\mathrm{t})=\mathrm{rb}\left(\cos (\mathrm{t})+\mathrm{t}^{*} \sin (\mathrm{t})\right) \\
& \mathrm{y}(\mathrm{t})=\mathrm{rb}\left(\sin (\mathrm{t})-\mathrm{t}^{*} \cos (\mathrm{t})\right)
\end{aligned}
$$
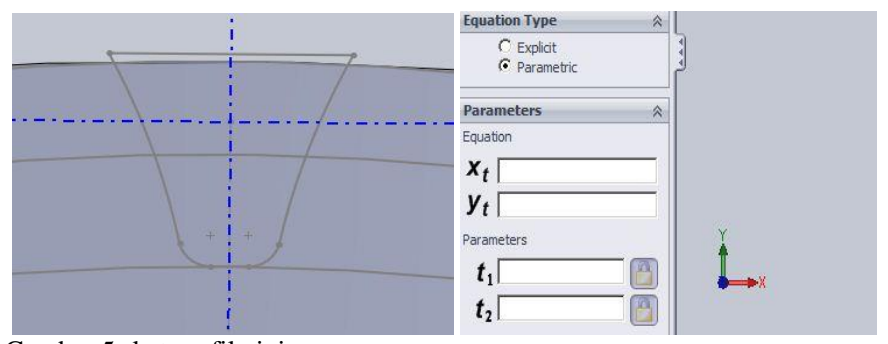

Gambar 5 sket profil gigi

Setelah part gear dan pinion selesai dibuat, selanjutnya dilakukan asembly sesuai mounting distance dan juga sudut poros yang sebelumnya sudah ditentukan.

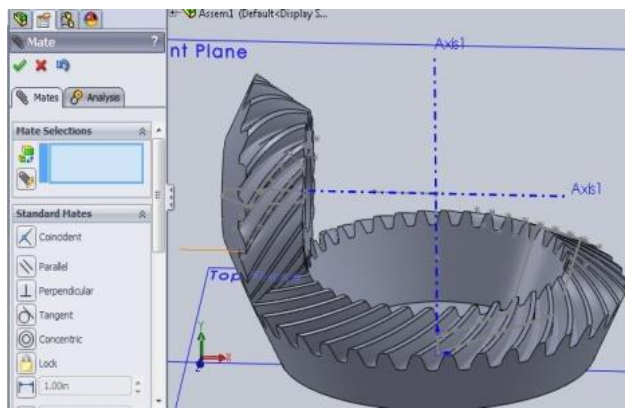

Gambar 6 Proses Assembly

\section{Simulasi}

Simulasi yang dilakukan berupa simulasi statis dan juga simulasi dinamis untuk mendapatkan nilai tegangan bending dan juga tegangan kontak maksimum. Simulasi statis dilakukan untuk menguji kekuatan bevel gear terhadap beban statis melalui bantuan software. Untuk melakukan simulasi ini diperlukan model 3 dimensi solid dari bevel gear hasil dari langkah pemodelan pada software CAD. Satu set model bevel gear diberikan tumpuan pada bagian bore gear dan diberikan beban berupa momen pada pinion. Bagian gear seolah-olah diam dan menahan beban yang diberikan. Setelah itu dilakukan proses meshing yang bertujuan untuk membagi area permukaan model menjadi beberapa bagian. Proses meshing ini menggunakan default mechanical mesh dan mapped face meshing pada bagian gear yang kontak agar hasil meshing lebih baik.

Setelah semua boundary condition ditentukan, solusi yang igin didapatkan dalam hal ini adalah tegangan contact dan juga tegangan bending. Untuk mendapatkan tegangan kontak diberikan contact stress berupa pressure. Sedangkan untuk tegangan bending didapat dari tegangan normal terhadap sumbu yang searah dengan tinggi gigi gear. Proses selanjutnya adalah menjalankan software untuk mendapatkan nilai dari tegangan bending dan juga tegangan kontakny setelah terlebih dahulu sebelumnya diberikan input momen sebesar $2500 \mathrm{lbf}$.in.

Simulasi dinamis dilakukan untuk mengetahui kekuatan 
bevel gear terhadap beban dinamis. Pada simulasi ini digunakan model yang sama seperti yang digunakan pada simulasi statis. Proses meshing pada simulasi dinamis ini juga mengikuti meshing yang digunakan pada simulasi statis. Perbedaan antara simulasi dinamis dan statis antara lain yaitu adanya fungsi waktu pada simulasi dinamis, gear dapat beputar, serta adanya input tambahan berupa kecepatan rotasi sebesar 1000rpm. Salah satu aplikasi bevel gear adalah digunakan pada transmisi kendaaraan khususnya roda 4. Sehingga pada penelitian ini nilai torsi dan putaran pada penelitian ini diambil dari aplikasi bevel gear pada kendaraan diesel pada putaran rendah.

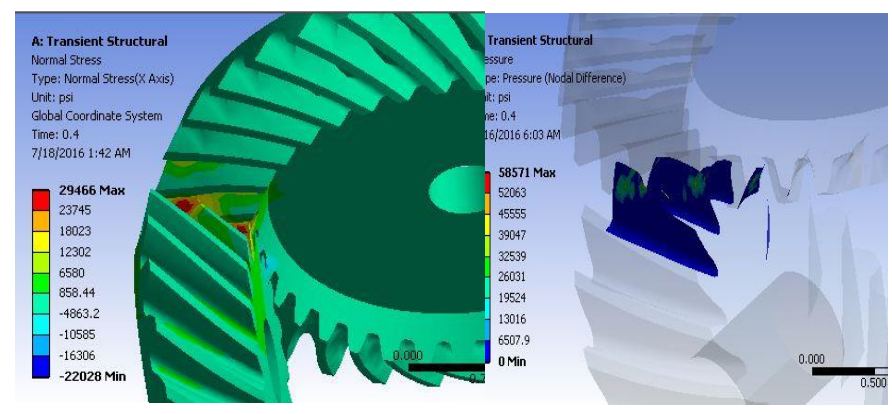

Gambar 7. Contoh Hasil Simulasi

\section{HASIL DAN ANALISA}

Pada sub bab ini akan ditampilkan beberapa hasil dari simulasi statis yang telah dilakukan dan keseluruhan hasil simulasi statis pada diagram hasil simulasi statis. Hasil yang didapatkan dari simulasi ini adalah tegangan bending dan juga tegangan kontak. Tegangan bending didapatkan dari tegangan normal yang tegak lurus dengan tinggi gigi. Sedangkan tegangan kontak didapat dari pressure pada contact tool.

\section{A. Perbandingan Simulasi statis dan perhitungan}

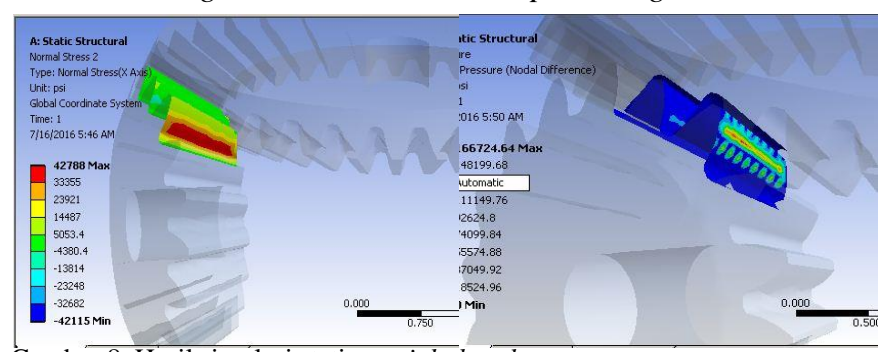

Gambar 8. Hasil simulasi statis straight bevel gear

Gambar 8 adalah hasil dari simulasi statis pada straight bevel gear. Simulasi statis pada straight bevel gear ini bertujuan untuk mengetahui akurasi dari proses desain 3D yang dilakukan. Dari hasil simulasi didapatkan tegangan bending maksimum pada straight bevel gear adalah 42788 psi, sedangkan tegangan kontak maksimum bernilai 166724 psi. jika di perhatikan, distribusi tegangan bending dan juga tegangan kontak terjadi gigi sepanjang gigi gear .

Terdapat perbedaan jika hasil simulasi statis diatas dibandingkan dengan hasil perhitungan analitis dimana didapatkan nilai tegangan bending sebesar 37793psi dan tegangan kontak sebesar 140072psi. Apabila selisih antara hasil perhitungan dan simulasi statis diprosentasekan maka selisih yang terjadi adalah 10,4\% pada tegangan bending dan 7,4\% pada tegangan kontak. Dilihat dari nilai prosentase perbedaan yang terjadi, dapat dikatakan jika langkah-langkah desain dan meshing yang dilakukan sudah valid.

\section{B. Tegangan Bending}

Tegangan Bending statis

dinamis

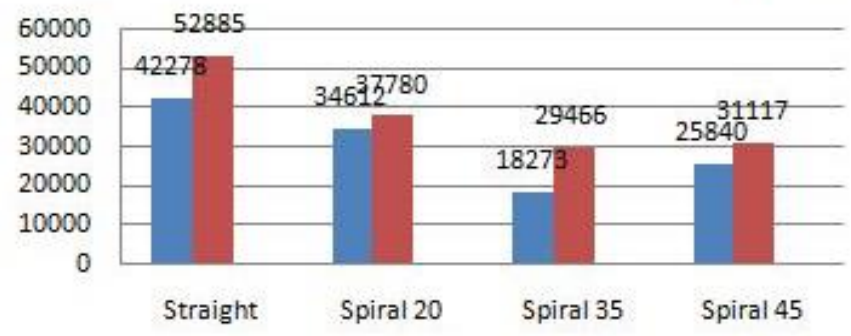

Gambar 9. Nilai Tegangan Bending

Gambar 9 adalah diagram perbandingan tegangan bending antara simulasi statis dan simulasi dinamis. Jika diperhatikan kedua diagram mempunyai trendline yang sama. Tegangan bending terbesar pada simulasi statis terjadi pada straight bevel gear dengan nilai 42278 psi dan tegangan bending terkecil terjadi pada spiral bevel gear 35 dengan nilai 18273 psi. Sedangkan pada simulasi statis tegangan bending terbesar dan terkecil juga terjadi pada straight bevel gear dan spiral bevel gear 35 dengan nilai masing-masing 52885 psi dan 31117 psi.

Secara keseluruhan nilai tegangan bending simulasi dinamis lebih besar daripada nilai simulasi statis. Hal ini terjadi karena adanya beban kejut yang terjadi pada simulasi dinamis. Pada simulasi dinamis pinion yang diberikan beban berupa torsi sebesar 2500 lbf.in dan kecepatan rotasi $1000 \mathrm{rpm}$ akan mendistribusikan torsi kepada gear melalui kontak gigi. Setelah akhir kontak dari gigi pinion terhadap gigi gear, gigi pinion tersebut akan kembali melakukan kontak pada gigi gear selanjutnya. Adanya celah dan juga jeda waktu antara akhir kontak menuju kontak baru inilah yang memungkinkan terjadinya beban kejut.

Penurunan yang cukup signifikan terjadi pada tegangan spiral bevel gear 35. Hal ini terjadi karena kelengkungan gigi 35 cukup besar yang mengakibatkan area kontak yang lebih luas dan terjadi pada lebih dari satu gigi. Pada spiral bevel gear 20 meskipun terjadi penurunan tegangan akan tetapi penurunan yang terjadi relatif kecil. Hal ini dikarenakan walaupun area kontaknya lebih luas karena adanya lengkung spiral, kontak gigi hanya terjadi pada satu gigi. Sedangkan tegangan pada spiral bevel gear 45 justru terjadi kenaikan jika dibandingkan dengan spiral bevel gear 35 baik tegangan bending maupun tegangan kontaknya. Faktor yang sangat mungkin menyebabkan hal ini terjadi adalah gaya axial yang semakin besar seiring dengan bertambahnya sudut spiral.

Berbeda dengan simulasi dinamis, pada simulasi statis tidak diberikan kecepatan rotasi. Selain itu tidak terjadinya gerakan dikarenakan bagian gear diberikan fixed support. Pada simulasi statis ini besar kecilnya tegangan juga sangat dipengaruhi pada assembly dari spasang bevel gear. Beban yang diberikan pada 
simulasi statis ini diberikan secara linear yaitu 0 psi hingga 2500 psi dalam waktu 1 detik. Sehingga pada simulasi statis ini tidak terjadi beban kejut, dan nilai tegangan yang terjadi lebih kecil jika dibandingkan simulasi dinamis.

Teori yang memperkuat alasan ini adalah berdasarkan perumusan AGMA tentang tegangan bending yaitu $\sigma_{t}=$ $\frac{F_{t} K_{o} P K_{S} K_{v} K_{m}}{2 \text { d.b.J }}$ [4], dimana $\mathrm{kv}$ merupakan koefisien dinamis. Semakin besar kecepatan rotasi gear, koefisien dinamis $(\mathrm{kv})$ ini juga semakin besar yang mengakibatkan tegangan bending menjadi semakin besar pula.

\section{Tegangan Kontak}

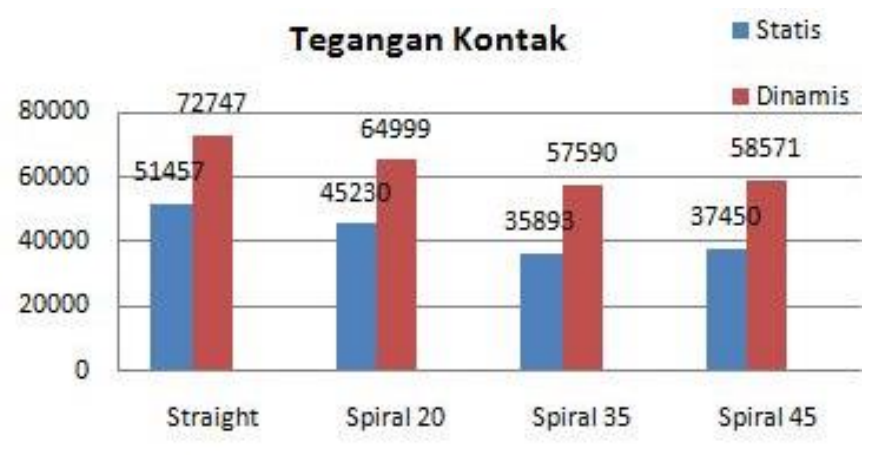

Gambar 10. Nilai Tegangan Kontak

Gambar di atas adalah diagram perbandingan tegangan kontak antara simulasi statis dan simulasi dinamis. Jika diperhatikan kedua diagram mempunyai trenline yang sama. Tegangan kontak terbesar pada simulasi statis terjadi pada straight bevel gear dengan nilai 166724 psi dan tegangan bending terkecil terjadi pada spiral bevel gear 35 dengan nilai 67923 psi. Sedangkan pada simulasi statis tegangan bending terbesar dan terkecil juga terjadi pada straight bevel gear dan spiral bevel gear 35 dengan nilai masing-masing 72747 psi dan 58590 psi.

Secara keseluruhan nilai tegangan kontak simulasi dinamis lebih besar daripada nilai simulasi statis. Hal ini terjadi karena adanya beban kejut yang terjadi pada simulasi dinamis. Pada simulasi dinamis pinion yang diberikan beban berupa torsi sebesar 2500 lbf.in dan kecepatan rotasi $1000 \mathrm{rpm}$ akan mendistribusikan torsi kepada gear melalui kontak gigi. Setelah akhir kontak dari gigi pinion terhadap gigi gear, gigi pinion tersebut akan kembali melakukan kontak pada gigi gear selanjutnya. Adanya celah dan juga jeda waktu antara akhir kontak menuju kontak baru inilah yang memungkinkan terjadinya beban kejut.

Berbeda dengan simulasi dinamis, pada simulasi statis tidak diberikan kecepatan rotasi. Selain itu tidak terjadinya gerakan dikarenakan bagian gear diberikan fixed support. Pada simulasi statis ini besar kecilnya tegangan juga sangat dipengaruhi pada assembly dari spasang bevel gear. Beban yang diberikan pada simulasi statis ini diberikan secara linear yaitu 0 psi hingga 2500 psi dalam waktu 1 detik. Sehingga pada simulasi statis ini tidak terjadi beban kejut, dan nilai tegangan yang terjadi lebih kecil jika dibandingkan simulasi dinamis.

Teori yang memperkuat alasan ini adalah berdasarkan perumusan AGMA tentang tegangan kontak pada bevel gear yaitu $\sigma_{c}=p_{h}\left(K_{a} K_{s} K_{m} K_{v}\right)^{1 / 2} \quad[4]$, dimana $\quad \mathrm{kv}$ merupakan koefisien dinamis. Semakin besar kecepatan rotasi gear, koefisien dinamis (kv) ini juga semakin besar yang mengakibatkan tegangan kontak menjadi semakin besar.

\section{IV.KESIMPULAN}

Dari hasil penelitian yang dilakukan dapat ditarik beberapa kesimpulan yaitu secara keseluruhan spiral bevel gear lebih kuat daripada straight bevel gear pada dimensi dan beban yang sama jika dilihat dari lebih kecilnya tegangan bending dan tegangan kontak maksimum yang terjadi. Tegangan terbesar terjadi pada jenis straight bevel gear dengan nilai tegangan bending sebeasar 52885 psi serta tegangan kontak 72747 psi pada simulasi dinamis. Variasi sudut spiral 35 mempunyai nilai tegangan terkecil baik dari tegangan bending maupun tegangan kotaknya yaitu sebesar 29466 psi tegangan bending dan 57590 psi tegangan kontak pada simulasi dinamis. Selisih tegangan bending dinamis yang terjadi antara spiral bevel gear 35 dan straight bevel gear sebesar 44,3\%. Sedangkan Selisih tegangan kontak dinamis yang terjadi antara spiral bevel gear 35 dan straight bevel gear sebesar 20,5\%. Dari uraian ini maka semakin besar sudut spiral tegangan yang terjadi semakin kecil karena semakin luasnya area kontak. Akan tetapi pada sudut spiral tertentu akan terjadi kenaikan tegangan dikarenakan gaya axial yang semakin besar.

\section{DAFTAR PUSTAKA}

[1] [1] G.M. Maitra, 2001. Hand Book of Gear Design Second Edition, Tata McGrawHill, New Delhi.

[2] Deutschman, Aaron D. 1975. Machine Design: Theory and Practice. New York: Macmillan Publishing Co, Inc.

[3] Baker J. Reynolds J. and Tecce, S.(2011). Parametric Design of a SpiralGear Process. Major Qualifying Report: JMS-1102 Worcester Polytechnic Institute.

[4] Dudley, Darle W, 1984, "Gear Tooth Design" in : nGear Handbook. McGrawHill Inc, USA. 